\title{
HOW COMPUTER TECHNOLOGY TRANSFORMS WRITING PERFORMANCE: AN INTEGRATION OF THE PROCESS/GENRE APPROACH AND BLOGS IN EFL WRITING COURSES
}

\author{
WEI-YU CHANG ${ }^{1 A} \&$ ANDREW SZANAJDA ${ }^{B}$ \\ ADurham University (UK) / B Overseas Chinese University (Taiwan)
}

\begin{abstract}
This quasi-experimental research examined the effects of the process/genre approach (PGA) with the integration of blogs in EFL university-level students' writing classrooms. This was a mixed-method study in which the participants' essays and adopted questionnaires contributed to accumulating quantitative data while the interviews and observations provided qualitative data. The study took place over ten weeks at a university in central Taiwan in which paper-pencil instruction was applied in the control group, while blog instruction was employed for the experimental group.
\end{abstract}

The students' essays were computed by applying a paired-sample t-test, and the questionnaires were analysed by applying a Wilcoxon signed-rank test to determine whether there were any statistically significant differences in terms of the students' writing performance and perceptions toward the PGA and blog writing after comparing the results of the pre-test and the post-test. The qualitative data was analysed to provide in-depth evidence to support the quantitative results.

After the data analysis was completed, the paired-sample t-test demonstrated that there were significant differences in terms of the students' writing performance in both groups, which demonstrates how the PGA developed the EFL university students' writing performance. Because the students had more interactive opportunities to be exposed to the language inputs, this approach facilitated their English writing performance. The Wilcoxon signed-rank test presented that the students revealed positive attitudes toward writing blogs and also positive affections toward blog writing because they had higher levels of satisfaction and lower levels of apprehension when blogging. Moreover, there was a significant difference in terms of the factor of "learning with peers" in the control group since the PGA provided more interactive and communicative opportunities. The students also indicated greater understanding about their writing samples in the experimental group, since they were allowed to refer to the instructional contents on the blogs anytime and anywhere.

Key words: Process/genre approach, blogs, EFL writing.

\section{Introduction}

In view of the accelerated growth and proliferation of computer technology in the twenty-first century, a variety of forms of computer technology have been introduced in foreign language (FL) education, which have greatly changed the way of how people learn foreign languages. One significant development is the advent of Web 2.0 provides language learners with a greater range of opportunities to communicate and interact in target languages with others, and helps students to learn collaboratively (Huang, 2015). Examples of communication software, such as Skype, Twitter, Google Talk, MSN Messenger, YouTube, My Space, Google Video, BBC, Blackboard, Blog, Facebook, and Wikis can all be used for language learning, while they support learners' language learning through socially interactive learning (Kervin \& Derewianka, 2011).

\footnotetext{
1 E-mail: anna.m.krulatz@hist.no
} 
Due to the features of being user-friendly (Fageeh, 2011; Noytim, 2010), there being ease of use and allowing for collaborative learning (Habul-Šabanović, 2015), blogs have been applied in different disciplines by educators to facilitate language teaching and learning (Blood, as cited in Armstrong \& Retterer, 2008). Although its effectiveness has been widely confirmed by many studies (Aljumah, 2012; Armstrong \& Retterer, 2008; Arslan \& Şahin-Kızıl, 2010; Fageeh, 2011; Kitchakarn, 2012; Lin, Groom \& Lin, 2013; Lin, Li, Hung \& Huang, 2014; Liu \& Chang, 2010; Noytim, 2010; Silviyanti \& Yusuf, 2014), the practical employment of blogging in language writing classrooms remains uncommon (Golonka, Bowles, Frank, Richardson \& Freynik, 2014; Miyazoe \& Anderson, 2010). Research on the investigation of the impacts of blog in language writing classrooms is also recommended (Aljumah, 2012).

Therefore, a study related to blog writing was conducted in Taiwan in which English learners learn English via regular classes, broadcasts, magazines, among other means, and most of them learn English through reiterative recitation and rote memorisation (Yang \& Chen, 2007)_Yang \& Chen, 2007) because English is not the vehicle for everyday communication in this EFL (English as a Foreign Language) learning context, and in actual fact, English is rarely used for daily communication in Taiwan (Wu, Yen \& Marek, 2011). Chen (2014) indicated that the rate of using English in different occasions among Taiwanese in daily life is really low, and they spend very little time to use English every day because English is very seldom used as a tool for cognition or socialisation in Taiwan.

In spite of the low rate of using English, the Taiwanese IELTS (International English Language Testing System) test-takers' overall band scores have recently been increasing. However, the writing results are the worst among the four language skills (listening, speaking, reading and writing) among Taiwanese IELTS candidates (Chen, 2015). Unfortunately, the skill of writing is deemed as one of the most difficult skills to improve (Lin, Yu, Wang \& Ho, 2015). Li (2010) indicated that one of the reasons for Taiwanese students' inadequate writing ability could be attributed to the examination systems, curriculum design, and learning attitudes because of the English education curriculum emphasis on being results-driven and score-oriented. This could greatly undermine students' English learning motivation (Li, 2012). Hence, the study intended to investigate whether the integration of the blog and process/genre approach (PGA) changed the Taiwanese university students' writing attitudes and improved their writing performances.

The PGA combines both the process approach (PCA) and genre approach (GRA) that was proposed by Badger and White in 2000 (Gao, 2012). In PGA writing classrooms, teachers have to provide as many similar social contexts as possible for learners, and also offer sufficient information for them to draw up the writing purposes (GRA). Students then use their language knowledge and skills to respond to writing tasks (PCA). Therefore, students will be able to use writing skills (PCA) to acquire greater linguistic knowledge (GRA), and understand the writing purposes (GRA), so their writing competence might be developed when their potential is motivated (PCA) and language inputs are provided (GRA) (Badger \& White, 2000).

According to the statements mentioned above, three pertinent research questions were raised in the study:

(1) In terms of the students' writing performance, does the PGA develop the EFL university students' writing ability?

(2) In terms of the students' perceptions toward the PGA, are there any statistically significant differences after the treatments?

(3) In terms of the students' perceptions toward blog writing, are there any statistically significant differences after the treatments?

\section{Review of the literature}

\subsection{The affordance of blogs in EFL writing classrooms}

The utilisation of Internet-based collaborative learning is increasing on account of its convenience, ease of use, and rapid development. This kind of learning provides a great number of opportunities for learners to obtain information and learn collaboratively (Boulos, Maramba \& Wheeler, 2006). Collaboration is an important element leading to successful learning because one's effective learning may be due to the 
participation and interaction with others' modelling behaviour and thought processes (Pawan, Paulus, Yalcin \& Chang, 2003). The concept of collaborative learning in a social-cultural environment has also been found in educational technology. It has been accepted that computer technology enriches social resources in one's learning process, and helps learners retrieve knowledge whenever and wherever they need. For example, the notion of computer supported collaborative learning enables learners to learn collaboratively in an Internet community, such as blogs (Selwyn, 2011).

Blogs are "up-to-the-minute posts, latest first" (Nardi, Schiano, Gumbrecht \& Swartz, 2004, p. 42) electronic journals to record users' written work in Internet communities (Johnson, 2004) in which learners of the same target language can convene together to practise using the language (Chapelle, 2010; Zhytska, 2012) so that their interactive connections could be developed (Top, 2012). Blogs are potential pedagogical alternatives in FL writing classrooms because they effectively develop students' writing ability in a collaborative manner (Normand-Marconnet \& Cordella, 2012; Silviyanti \& Yusuf, 2014; Warschauer \& Liaw, 2011), and they serve as a complementary role to traditional (face-to-face) classrooms for FL education (Normand-Marconnet \& Cordella, 2012).

The application of blogs in FL writing classrooms may be very helpful to instructors. Not only can blogs improve students' writing contents and organisation of these contents, but also allow for students to easily receive and give feedback without there being restrictions of time and place. Some beneficially supplementary and auxiliary materials, such as pictures, sound or video files that convey meanings and inspire students' language learning could be uploaded to blogs as well (Armstrong \& Retterer, 2008; Torut, 2000). Hence, a teacher's instruction is not confined to face-to-face instruction, since instructors and learners can meet whenever and wherever necessary (Arslan \& Şahin-Kızıl, 2010). As for students, they can read others' writing samples, share their comments, and come to understand how to edit each other's contents. It is also convenient to correct and re-write essays on blogs because they save writers' time by being much faster than conventional writing, and therefore are more productive for writers to compose essays. Required information can be also retrieved when the contents are found online. Consequently, writing blogs develop FL learners' writing competence, increase their writing motivation, and improve their learning autonomy (Sun, 2010). Students are thus able to gain more opportunities to learn FL writing through functioning on this quick and easy operating platform (Warschauer \& Liaw, 2011).

Lin et al. (2014) pointed out that blog writing generated lower levels of anxiety and improved performance among EFL learners. They found that the students might be relieved of apprehension when writing on blogs, which contrasts with another group of students who wrote with pen and paper. Moreover, the majority of the participants in Aljumah's (2012) study reflected that they enjoyed the blogging programme where they posted entries, read posts, and gave comments. The participants had very positive attitudes toward the use of blogs in English writing classrooms, so they believed that blogs were useful, motivational and effective in developing their writing ability. Fang (2010) also indicated that the majority of the students under study were quite satisfied with the blog writing programme, and there was a positive effect on the development of the learners' writing skills. Therefore, the students had very positive attitudes toward the use of computer technology in writing classrooms, and revealed how they expected to have a programme of this kind in their future writing classes. Armstrong \& Retterer (2008) conducted a study with reference to the use of blogs in Spanish writing classes, and found out that most of the participants (more than $80 \%$ of them) enjoyed writing on blogs because they were easy accessible, and online references and dictionaries could be easily accessed.

However, some counter viewpoints have been posited about using blogs in writing classrooms. Lessproficient students might not feel sufficiently confident about posting their entries on blogs, which could result in negative affections about blog writing, such as losing face among peers, which is to be considered a grievous matter in Asian classrooms. Also, the instruction method in a blog community is student-centred rather than teacher-directed, which might influence students' learning, including among Taiwanese students in particular. Because Taiwanese students have long been dependent on the teachers in classrooms, in which they expect to receive "correct" answers from their teachers, they might feel uncertain about or uncomfortable with their contents while they are writing in an open blogosphere (Lin, 2015). Also, a peer's feedback only serves a pragmatic function with the possibility of there being extravagantly complimentary words, rather than a linguistic function through providing useful and constructive comments (Wu, 2006). Similarly, commenting on peers' writings might make the students feel embarrassed and even ashamed if 
they make mistakes, so they would rather leave encouraging messages for their peers to avoid committing mistakes (Lin et al., 2013). Thus, Aljumah (2012) concluded that peers' feedback was neither helpful nor useful for students' writing development on blogs, especially when the students did not know how to comment or what to comment about on others' entries. In addition, students might also fail to respond to the teacher's feedback while revising their writings because of their insufficient English abilities (Wu, 2006).

\subsection{The process/genre approach}

The process/genre approach (PGA) that combines both the process approach (PCA) and genre approach (GRA) was proposed by Badger and White in 2000 (Gao, 2012). The PCA, which views writing as a natural process and emphasises students' creativity and effectiveness to produce a written text (Maybin, 1994), is more learner-centred (Matsuda, 2003; Nordin \& Mohammad, 2006; Tuffs, 1993). In contrast, the GRA is more teacher-centred (Hyland, 2007), so the teachers are responsible for the students' writing development and have to evaluate how successfully the students have learned to achieve tasks toward a specific genre (Maybin, 1994). Despite the differences between the two approaches, they can complement each other because one motivates students' learning and provides learning opportunities through the writing process, while the other helps students understand what linguistic structures are required for a particular genre (Maybin, 1994). Hence, the consolidation of the PCA and GRA becomes more effective to help students understand writing process in a genre when constructing a text (Bijami \& Raftari, 2013).

In PGA writing classrooms, teachers have to provide as many similar social contexts as possible for learners and offer sufficient information for them to draw up the writing purposes (GRA), and then students use their language knowledge and skills to respond to the writing tasks (PCA). Therefore, students will be able to use the writing skills (PCA), realise more linguistic knowledge (GRA), and understand the writing purposes (GRA), so their writing competence might be developed when their potential is motivated (PCA) and language inputs are provided (GRA) (Badger \& White, 2000). Gao (2012) proposed five instructional steps to introduce how the PGA is implemented in EFL writing classrooms, which include model paper analysis and demonstration, group discussion and imitation, individual imitation and writing, whole-class comment and modification and final drafting and publication.

1. Model paper analysis and demonstration: this phase is similar to the pre-writing stage. Teachers provide model texts for students to analyse, and students understand the genres, writing structures, writing purposes, and linguistic features, among similar considerations. Also, powerful and impressive arguments and expressions should be highlighted and demonstrated.

2. Group discussion and imitation: in this stage, 3 or 4 students form a small group to discuss the theme toward their writing tasks, including the writing style, organisation, expression, grammar, and then discuss how they would construct their writing frameworks or how they would perform their linguistic features for this theme.

3. Individual imitation and writing: students practically write essays in this phase in which they use the writing structures and linguistic features that they have learned from the previous stages into their writing samples. They have to compose an essay with introduction, body and conclusion paragraphs.

4. Whole-class comment and modification: before a whole-class discussion, teachers have to categorise the students' written work according to the marking results and then demonstrate the students' written texts in class. Whole-class discussion is based on both the well-written and poorlywritten essays so that students are able to compare and contrast their own writings with samples for correction.

5. Final drafting and publication: finally, students work on their final draft before submission. The previous four stages are involved in the final step in order to make sure that students understand the genres, writing structures, writing purposes, and linguistic features, among similar considerations.

However, the instructional procedures in the PGA are recursive, so both the teachers and students could return to the previous steps if necessary. 


\section{Methodology}

\subsection{Research design}

The primary purpose of the study was to examine whether the integration of using a blog and the PGA developed the EFL university students' writing performance by comparing the outcomes collected from the control group and the experimental group in both the pre-test and post-test. To achieve the main purpose of the study, a quasi-experimental design was adopted in this study. The purpose of a quasi-experimental study is to determine the impact of curricular materials or teaching methods (McMillan \& Schumacher, 2010), and this kind of research design is able to produce a great deal of knowledge and find reasonable outcomes and conclusions (Ary, Jacobs, Sorensen \& Walker, 2014; Gall, Gall \& Borg, 2010). To fulfil the research purpose, the study was therefore designed based on Creswell's (2012) Quasi-Experimental Design: Preand Post-test Design which was shown in Table 1.

Table 1. The Adopted Quasi-Experimental Design: Pre-test and Post-test Design Time

\begin{tabular}{|c|c|c|c|}
\hline Groups & Pretest & Treatment & Posttest \\
\hline $\begin{array}{l}\text { Control } \\
\text { Group }\end{array}$ & $\begin{array}{l}\text { English Essays } \\
\qquad+ \\
\text { Questionnaires }\end{array}$ & $\begin{array}{l}\text { Traditional Writing Class } \\
\text { (no treatment): } \\
\text { Paper-pencil-based } \\
\text { Instruction + } \\
\text { Observations }\end{array}$ & $\begin{array}{l}\text { English Essays } \\
+ \\
\text { Questionnaires } \\
+ \\
\text { Interviews }\end{array}$ \\
\hline $\begin{array}{c}\text { Experimental } \\
\text { Group }\end{array}$ & $\begin{array}{l}\text { English Essays } \\
\qquad+ \\
\text { Questionnaires }\end{array}$ & $\begin{array}{l}\text { Technology Writing Class } \\
\text { (with treatment): } \\
\text { Computer (Blogs)-based } \\
\text { Instruction + } \\
\text { Observations }\end{array}$ & $\begin{array}{l}\text { English Essays } \\
+ \\
+ \\
\text { Questionnaires } \\
+ \\
\text { Interviews }\end{array}$ \\
\hline
\end{tabular}

As can been seen in Table 1, there were two classes of students participated in the study who were randomly labelled as the control and experimental groups, and also had the same instruments in the pretest, including the application of the English essays and questionnaires. During the treatment phase, the participants in the control group received paper-pencil instruction while blog instruction was infused into the experimental group. The students in both groups received the same materials given by the same instructor with the same length of instruction time. At the same time, the instructor and another experienced writing instructor observed the classes together. After the treatments, the identical instruments administered in the pre-test were employed for all the participants again in the post-test. Finally, seven individuals in each group were randomly selected for the retrospective semi-structured interviews.

\subsection{Participants}

A total of 34 second-year undergraduate English majors were consulted in this research while they were studying English writing as a required course at a university in central Taiwan in the autumn/winter of the 2014 academic year. The two classes of subjects were randomly labelled as the control group and the experimental group. In the control group, there were 16 female students, aged from 18 to 20 with an average age of 19.125; in contrast, there were 18 students, including 4 males and 14 females, in the experimental group, aged from 19 to 20 with an average age of 19.055. The participants' English proficiency in these two groups were quite similar according to their university entrance exam results provided by the Testing Centre for Technological and Vocational Education, which is the most authoritative testing centre for technological 
and vocational education in Taiwan. All of the students who finish their study at technological and vocational high schools have to take the test to study at universities in Taiwan. Unfortunately, it was impossible to have more students to enrol in the classes because it was a required course for English majors in the department, and only two classes were available for the researcher to conduct the study. Of practical concern is writing classes usually have lower number of students, which is acceptable as an argument for research purposes (Lin, 2014, 2015), and therefore the number of the participants in the current study should be considered adequate.

\subsection{Research instruments}

Writing Essays - The topic of the English writing essay was chosen from the teaching material, 全民 英檢一路通: 中級寫作能力測驗 (A Pathway to the General English Proficiency Test: Writing Proficiency Test for the Intermediate Level) written by Chen (2013), used in the current study. The purpose of using this book as the primary source material was its appropriateness since the contents of the books suited the course requirements and the students' needs. Considering the participants' English abilities, the materials were appropriate to their needs because this textbook is designed for those who are preparing for the intermediate level (equivalent to CEFR B1) of the General English Proficiency Test (GEPT), which is set up by the Language Training and Testing Centre, Taiwan. This is one of the accepted indices for admissions to universities and graduate schools in Taiwan, and it is also widely accepted by many governmental institutions or private organisations for recruitment or promotion in Taiwan. This textbook was therefore used in this study to help prepare students to pass the GEPT.

Questionnaire - In this study, there were two sets of questionnaires: the Questionnaire for the Process/Genre Approach (QPGA) and the Questionnaire for Blog Writing (QBW). The former one was constructed by the researcher since the PGA is relative new in language writing education, and a proper ready-made questionnaire could not be found. The self-made QPGA was formed following previous studies (Badger \& White, 2000; Gao, 2012; Nordin \& Mohammad, 2006; Yan, 2005) that have discussed the PGA in detail. As for the QBW, it was revised based on Aljumah's (2012) questionnaire, which has been cited as being reliable and validated. The Aljumah's study was akin to the current study in certain ways: (a) all of the participants were English majors at the university level; (b) they all learned English in EFL contexts; (c) the study was also related to English writing; and (d) blogs were the teaching and learning means in the research. Therefore, Aljumah's questionnaire was suitable for the current study as an appropriate option. Because the questionnaires were either self-constructed or revised based on an existing one, a pilot study was conducted to make sure the reliability and validity before applying a formal utilisation. In the pilot study, the techniques of expert judgement, factor analysis, test-retest reliability, internal consistency reliability, and interviewing were carried out, so the researcher would be able to establish the reliability and validity of the questionnaires. Lastly, all of the items were dislocated according to the arrangement produced by the Researcher Randomizer (Urbaniak \& Scott, 1997) in the finalised version.

Observation - The researcher and the other experienced writing instructor observed the classes together based on the observation checklist provided which was designed by the researcher and was reviewed by two experts before the formal application. The researcher acted as a participant observer so that all of the instructional procedures had been done and could be likewise confirmed, in addition to developing classroom rapport with the participants to increase the feasibility to gather a great deal of information during the interview phases. The other instructor was a second observer who acted as a nonparticipant observer, so any bias during the observation phase could be avoided, and the reliability of observation might be improved (Curtis, Murphy \& Shields, 2014).

Interview - In the current study, retrospective semi-structured interviews were adopted because the participants needed to cast back what happened while they were writing and what happened while they were in class in order to complete the interview questions that were designed following the contents of the questionnaires prior to the interviews in order to answer the research questions. Eight questions were respectively designed for the participants' perceptions toward the PGA and blog writing. Nevertheless, in order to ensure the validity of the interview questions, two experts who have doctorate degrees and have been teaching English in EFL contexts for years were invited to review the interview questions. Five students 
were then invited for the pilot test to ensure the questions were understandable to the participants and pertinent to the study.

\subsection{Data collection}

Blog - Due to the research needs, all of the participants in the experimental group were asked to register an account on www.pixnet.net, which is free of charge and easy for users to manipulate. The PIXNET was launched in 2003 and offers blogs, online albums, guest books, and web communities. The reasons for selecting the PIXNET were: (a) it is a Taiwanese website, so the participants might feel more familiar with its interface; (b) some troubles might be avoided while the participants were using it; and (c) it saved the researcher's time to introduce how to use the blogs.

After the students registered on PIXNET with a personal account, the students were asked to provide their account IDs to the researcher in order to publicise contents for the other students to see for the future needs. The researcher compiled the students' blog account IDs and announced all of them on a tutor blog so that the students were able to link or crosslink to others' blogs during the experimental period. The tutor blog served the functions of making course announcements as well as distributing teaching materials and feedback provisions. Therefore, it served as an online notice board for the researcher and the participants because some reminders were necessarily made in order to ensure the students were submitting their essays on time and duly receiving class announcements duly. All of the teaching materials could be distributed before the classes started, so it helped the researcher have the participants preview the teaching contents in advance. The researcher was also able to conveniently provide feedback on the subjects' writing samples at different times from various locations. The students used their blogs (the learner blog) to receive course announcements, preview and review teaching materials, upload their assignments, and give feedback to each other.

The Course - The data collection in the current study took place at a university in central Taiwan in the autumn/winter of the 2014 academic year. In order to prepare the students to cope with functioning in competitive workplaces or further studies after completion of their university studies, writing courses were designed as required ones throughout the students' four-year university study. On account of the accessibility and availability of the classes, the study was applied to second year undergraduates who had a year of writing training at university before taking part in this research study. This was a weekly two-hour writing class with a total of 18 weeks in a semester.

Procedures - The procedures in the study included the pre-test, treatment, post-test, and the interview. In the pre-test, all of the students were given thirty minutes to complete the writing essay, and the questionnaire booklets were given to the participants afterwards.

The treatments were then respectively given to the two groups for eight weeks. In the control group, all of the teaching materials were prepared in advance and were handed out by the researcher in class. The students' assignments were also handed in on paper. In contrast, all of the instructional materials were uploaded to the tutor blog by the researcher before classes began, and the students in the experimental group had to post their assignments on their own blogs before the deadlines. Apart from the teaching tools, the teaching procedures and approaches were really similar in the two groups in which the instructor explained the model articles and elicited the students' ideas. The students discussed the ideas with their peers and provided their findings after their discussions in class. Then, they wrote an essay that was turned in every week. The students' writings were also used as the teaching materials after the researcher's marking. The students had to modify their essays based on the comments given by either the instructor or their peers, and turned in their new writing essays together with the modified one every week. At the same time, the researcher acted as a participant observer while the other was a non-participant observer during the treatment phase. The observation checklists were also completed.

Finally, the post-test whose procedures were quite akin to those in the pre-test were conducted a week after the treatments. In the post-test, the identical writing essay and the questionnaires used in the pre-test were distributed to the subjects.

Interview - The interviews were conducted in the following weeks after the post-test. The students' native language, Mandarin Chinese, was used in the interviews to reduce the interviewees' levels of anxiety 
and motivate their willingness to participate, so much more information could be expected to be collected during the interviews. A total number of fourteen interviewees from the two groups were randomly chosen and took part in the interviews. Most of them finished the interviews in thirty minutes. Then, the researcher transcribed all of the interviews and translated them into English.

\subsection{Data Analysis}

Quantitative Data Analysis - The quantitative data comprised the students' writing essays as well as the questionnaires, and all were involved in both the pre-test and post-test. IBM SPSS Statistics version 22 was used to calculate the numerical data in which both the descriptive and inferential statistics contributed to the quantitative results. In the current study, the paired-sample $t$-test was applied in the study to determine whether there were any significant differences between the pre-test and the post-test in the two groups in terms of their English writing performance based on Hughey, Wormuth, Hartfiel, and Jacobs's (1983) English as a Second Language Composition Profile, because this statistical tool is usually used to compare two sets of scores collected from a pre-test and a post-test completed by the same group of participants (Brace, Kemp \& Snelgar, 2012; Dörnyei, 2007; McMillan \& Schumacher, 2006). Then, a Wilcoxon signed-rank test, a nonparametric test, which is equivalent to the paired-sample $t$-test (Field, 2013) was used to compare the data collected from the questionnaires to see whether there were any significant differences between the two sets of data collected from the pre-test and post-test.

Qualitative Data Analysis - In virtue of the manageability of the observational data, the researcher could simply use Microsoft Office Word software to note, edit, store, retrieve, link, and highlight the data. The researcher, firstly, input all of the raw data collected from the observations in a Word file, which were then read and re-read repeatedly to find connections and the relationships in the two categories of the observational data (i.e. the instructor's instruction and learners' learning) that was recorded by the two observers. After receiving the preliminary ideas of the observational data, the researcher then conducted the further analysis to look into the possible answers for the observed phenomenon so that it was possible to provide more accurate and robust research findings, and then compare and contrast them with the interview results in the subsequent discussions.

As for the interview data analysis, the participants' native language, Mandarin Chinese, was used in the interviews, and all of the interview processes were audio recorded. The researcher therefore had to transcribe the interview responses and translate them into English. Since electronic recording was used in the interview process, the researcher was able to reproduce the data for the sake of fully understanding the given information. During the transcribing process, the researcher had the opportunity to deliberate the meanings of the given information since transcription is a process of construction, rather than merely recording what was said (Hammersley, 2010). The researcher was thus able to compare and contrast the interview data with facts from the observations.

\section{Quantitative data results}

Table 2. Descriptive Statistics of the Participants' English Writing Performance

\begin{tabular}{ccccc}
\hline & \multicolumn{2}{c}{ Control Group } & \multicolumn{2}{c}{ Experimental Group } \\
\cline { 2 - 5 } & Pre-test & Post-test & Pre-test & Post-test \\
\hline Mean & 53.1563 & 68.4063 & 53.8056 & 70.7222 \\
$\mathrm{~N}$ & 16 & 16 & 18 & 18 \\
Std. Deviation & 4.5596 & 7.1162 & 6.8944 & 7.2967 \\
\hline
\end{tabular}


Table 2 described the mean scores of the pre-test and post-test regarding the participants' English writing performance between the two groups. In the pre-test, the mean scores were 53.1563 and 53.8056 respectively in the control group and the experimental group, with a slight difference of 0.6493 . However, the mean scores in the post-test were 68.4063 in the control group and 70.7222 in the experimental group. The difference of the mean score between the two groups was 2.3159. The result in the experimental group was higher than that in the control group, and the difference in the post-test was greater than in the pretest's.

Table 3. Paired-Sample t-Test of the Participants' English Writing Performance

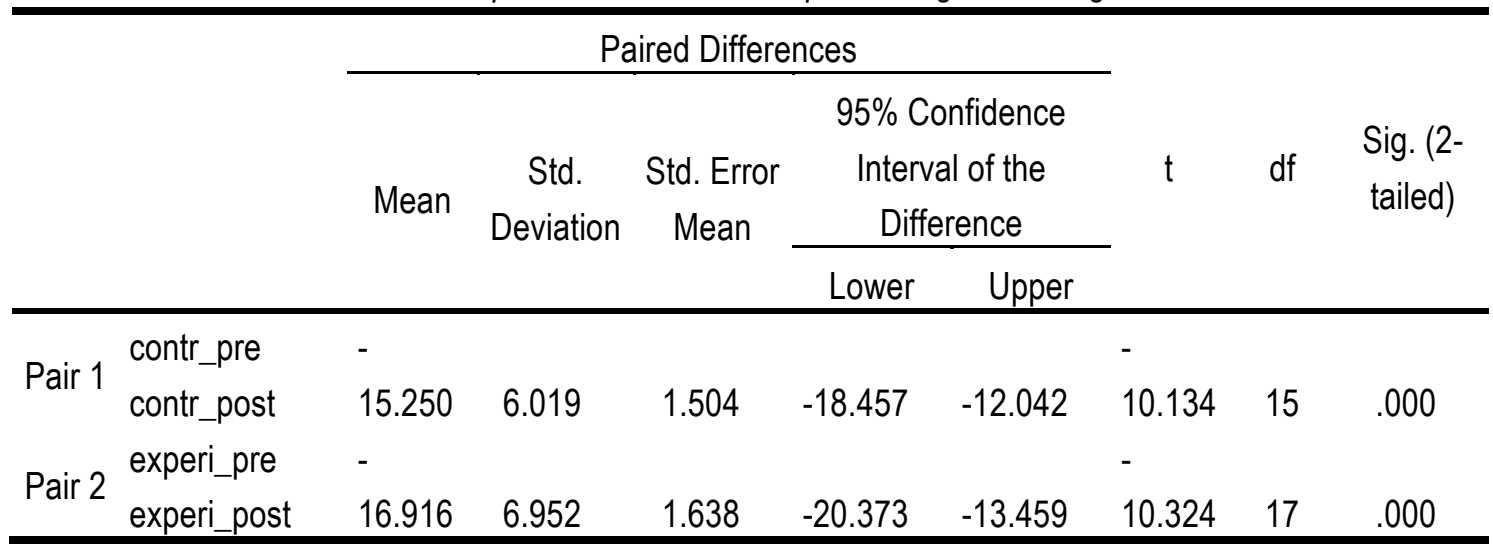

As presented in Table 3, the paired-sample $t$-test demonstrated that there were significant differences in terms of the participants' English writing performance in both the control group and the experimental group. The mean score was $-15.250(p=.000<.05)$ in the control group, while it was $-16.916(p=.000<.05)$ in the experimental group. Therefore, the test certified that the participants' English writing proficiency had been significantly improved after the treatments in both groups.

Table 4. Wilcoxon Signed-Rank Test of the QPGA in the Control Group

\begin{tabular}{lcccc}
\hline & TF2 & LwP2 & UfW2 & MAEW2 \\
& - & - & - & - \\
& TF1 & LwP1 & UfW1 & MAEW1 \\
\hline Z & -.288 & -1.758 & -1.084 & -.957 \\
Asymp. Sig. (2-tailed) & .773 & .079 & .279 & .339 \\
Exact Sig. (2-tailed) & .797 & .092 & .345 & .362 \\
Exact Sig. (1-tailed) & .399 & .046 & .172 & .181 \\
\hline
\end{tabular}

Table 4 reported the statistical results of the QPGA in the control group after the treatments, which were analysed by Wilcoxon signed-rank test. It can be found that there was no significant difference in the 2-tailed test. Nevertheless, the question of the study was to realise whether there were any significant differences after the treatments, so 1-tailed test should be taken into account. The results in the 1-tailed test figured out that there was a significant difference in the sub-category of learning with peers (LwP) $(p=.046<.05)$ in the control group. 
Table 5. Wilcoxon Signed-Rank Test of the QPGA in the Experimental Group

\begin{tabular}{lcccc}
\hline & TF2 & LwP2 & UfW2 & MAEW2 \\
& - & - & - & - \\
& TF1 & LwP1 & UfW1 & MAEW1 \\
\hline Z & -1.230 & -.679 & -2.411 & -1.711 \\
Asymp. Sig. (2-tailed) & .219 & .497 & .016 & .087 \\
Exact Sig. (2-tailed) & .233 & .521 & .016 & .104 \\
Exact Sig. (1-tailed) & .117 & .260 & .008 & .052 \\
\hline
\end{tabular}

The differences of the QPGA between the pre-test and post-test in the experimental group were analysed by applying a Wilcoxon signed-rank test that is illustrated in Table 5 . The statistical results pointed out that one significant difference was found in the sub-category of understanding for writing (UfW) ( $p=.016<.05$ ). Nevertheless, the study tried to find out whether there were any significant differences after the treatments, so the results of the 1-tailed test was also presented in Table 5 . However, the outcomes were similar to the aforementioned consequences in which only one significant difference was found in the sub-category of understanding for writing (UfW) $(p=.008<.05)$.

Table 6. Wilcoxon signed-rank test of the QBW in the Experimental Group

\begin{tabular}{|c|c|c|c|c|c|}
\hline & $\begin{array}{c}\text { BvPW2 } \\
- \\
\text { BvPW1 }\end{array}$ & $\begin{array}{c}\text { BEW2 } \\
- \\
\text { BEW1 }\end{array}$ & $\begin{array}{c}\text { BFS2 } \\
- \\
\text { BFS1 }\end{array}$ & $\begin{array}{c}\text { ATTI2 } \\
- \\
\text { ATTI1 }\end{array}$ & $\begin{array}{c}\text { AFFE2 } \\
- \\
\text { AFFE1 }\end{array}$ \\
\hline Z & -.667 & -.530 & -1.424 & -1.900 & -1.929 \\
\hline Asymp. & & & & & \\
\hline $\begin{array}{l}\text { Sig. } \\
\text { (2-tailed) }\end{array}$ & .505 & .596 & .155 & .057 & .054 \\
\hline $\begin{array}{l}\text { Exact Sig. } \\
\text { (2-tailed) }\end{array}$ & .513 & .622 & .165 & .053 & .055 \\
\hline $\begin{array}{l}\text { Exact Sig. } \\
\text { (1-tailed) }\end{array}$ & .257 & .311 & .083 & .027 & .027 \\
\hline
\end{tabular}

As can been seen in Table 6, the results of the Wilcoxon signed-rank test (2-tailed) indicated that there was no significant difference in terms of the students' perceptions toward blog writing among the five subcategories after the treatments in the experimental group. However, the study focused on the understanding of the differences after the treatments, which was a 1-tailed test, so the $p$ value in the 2-tailed test should be divided by 2 . Therefore, it was found that there were significant differences in terms of the students' attitudes toward blog writing $(p=0.27<.05)$ and affections toward blogs writing $(p=0.27<.05)$.

\section{Qualitative data results}

Observation - In terms of the students' interactions in class, the students tended to be passive and reticent during the discussion phase, which was found to be in stark contrast to their activity during the interviews when they were found to be livelier. Although the PGA increased the numbers of the students' interaction with either the instructor or peers, they were prone to be reserved when they were asked to provide their opinions, which could be partly due to the nature of the Taiwanese educational system, in 
which Taiwanese students usually expect the "ideal' or "correct" answers from their instructors, and therefore lack the confidence to voice their ideas in class. However, the PGA still increased their interaction and communication with others during their writing process because they usually wrote individual samples before participating in the study.

Also, the peers' comments on the blogs were not very constructive in terms of English writing development because the students usually provided encouraging words (e.g. Your writing is good.) rather than offering critical comments to their peers. The possible reasons were: (1) they did not know what to comment on; (2) they were not confident enough to make comments; (3) they were afraid to undermine their friendships with classmates; (4) they were afraid making mistakes in their comments. However, it was also found that giving face-to-face comments might be more effective because the students have opportunities to discuss with their peers or clarify their contents verbally. Therefore, integrating both in-class face-to-face discussions and after-class online discussions to enhance the students' language learning is recommended (Huang, 2015)

Interview - In terms of the students' perspectives toward the PGA, most of the interviewees confirmed the effects of the PGA in the writing classrooms. They found that they were able to understand writing directions more easily, think of writing ideas more easily, and start writing more easily. All of these separate factors helped them learn writing contents more efficiently. It was found that the provision of the model articles as well as the instructor's instruction developed their writing potential. By doing so, the students could understand how to pave the way in their writings and refer to the model articles when they had difficulties in writing, so they could think of writing ideas through the model articles and start their writing samples more easily. They also pointed out that they learned a great deal of vocabulary, since they had to read the model articles before writing and read others' written work during the whole process. Therefore, the students had many opportunities to be exposed to language inputs, which not only improved their language abilities, but also developed their critical thinking abilities. More importantly, collaborative and interactive learning was enhanced in the programme. The interviewees mentioned that they had more interaction with the instructor and their peers than usual, which helped them understand how to learn from others. However, a major difference between the two groups was the students' ownership and readership were possibly enhanced when they were writing blogs, but this was not found for the other group. This might be because the students in the experimental group realised anyone could read their writing blogs, and they understood they were writing for communication rather than for assignments.

In terms of the blog writing, the interviewees expressed they had a wider range of learning and interactive opportunities with others. It was easier for them to read other's written work, they were able to leave comments to each other, and writing on blogs involved having less apprehension and anxiety about completing writing tasks. Furthermore, the students might not expect too much from the instructors, as Taiwanese students often rely on the instructors to give them "the best" answers in class. In other words, they were likely to seek solutions by themselves before posting their writing samples on blogs in order to avoid making mistakes before the instructor marked those samples. Consequently, autonomous learning was encouraged. The most prominent finding was most of them mentioned the effectiveness of collaborative learning when blogging. Many of the interviewees noted that they were able to learn from their peers, and they could refer to others' written work when they had no ideas about how to complete writing samples. In addition, their linguistic knowledge was increased when they were reading others' writings. As a result, not only could the students' language abilities or writing competence be developed, but their perceptions toward collaborative and autonomous learning could also be improved.

\section{Discussions} Research Question 1: In terms of the students' writing performance, does the PGA develop the EFL
university students' writing ability?

According to the quantitative results (Table 2 and 3), the PGA developed the students' writing performance in both groups, so it was confirmed that the PGA was conducive to the students' writing development no matter what kind of writing classrooms they were in. According to the interview results, the offer of the model articles and the instructor's instruction made the participants aware of the writing 
directions, supporting ideas, writing structures, and they also helped the students start the writing easily, focus on the writing topics and collect examples for their writings. However, the researcher found that the model articles and the instructor's instruction are inseparable. That is to say the provision of the model articles might not completely solve the students' writing difficulties, and the instructor's teaching might not fully clarify the students' understanding about completing writing tasks. Therefore, the effectiveness of using model articles could be maximised along with providing a sufficient amount of instruction time, and instruction could greatly meet students' needs with appropriate model articles.

Moreover, the PGA not only develops the students' English writing performance, but also promotes interaction with others. In PGA-based writing classrooms, the students need to interact and communicate with their peers or instructors in order to brainstorm and gather writing ideas together, rather than start with an individual work, so the students could form a social writing network with others. Having more interactions with the peers or the instructor was largely pointed out in the study interviews, which enhanced the students' writing performance because the students were able to learn from others, had more opportunities to be exposed to language inputs, and receive greater opportunities to train their critical thinking abilities. As a result, the social writing network benefited the students' understanding concerning their writing tasks.

Although there were statistically significant differences in both groups in terms of their English writing performance, the mean score of the post-test in the experimental group was higher than the control group's (mean score $=70.7222>68.4063$ ). Although the difference of 2.3159 was not really conspicuous, it was greater than the results in the pre-test, in which the difference was 0.6493 (experimental group $=53.8056>$ control group $=53.1563)$. Therefore, the researcher concluded that the students in the blog-based writing classroom performed better than those who were in the paper-pencil-based writing classroom. The possible reasons were the students in the experimental group: (a) could perceive the senses of readership and ownership, so they might pay more attention to verify their writings in order to make them more comprehensible; (b) had more chances to be exposed to the language inputs because they could easily retrieve required information on the Internet and refer to others' writings for their own writings; and (c) had less apprehension and anxiety while they were writing because they had more resources, and could also communicate and interact with others on blogs.

\section{Research Question 2: In terms of the students' perceptions toward the PGA, are there any statistically significant differences after the treatments?}

The quantitative results for the research question are shown in Tables 4 and 5 . The results demonstrated that only a significant difference was found in each group. In the control group, the dimension of "learning with peers" showed a statistically significant difference at $p=.046<.05$, and the outcome for the "understanding for writing" was $p=.008<.05$ in the experimental group. This might be because the students in the control group had "genuine" interactions with their peers at all times. In other words, the students in the experimental group read others' work, read others' feedback, or left comments to others on blogs, which might not arouse the students' senses of interaction because all the interactions were conveyed through computers, rather than in person. Additionally, the students in the control group were able to compare their learning experience in this programme with their previous experiences, both of which were completed through paper-pencil instruction, so they could conspicuously find the differences of "learning with peers." With regards the consequence in the experimental group, the students were allowed time for previewing and reviewing the teaching contents, reading their peers' work or retrieving required information whenever they wanted and wherever they were, so they had more chances to involve in the learning context, which very likely improved their understanding of the writing tasks.

Unfortunately, it has to be noted that the PGA is not without its disadvantages. The researcher found that limited creativity, lengthy teaching time, and reticent students might be potential barriers for teachers who apply the PGA in EFL writing classrooms. Firstly, the students' writing creativity might be confined to the model articles provided. Because the students must understand the model articles before commencing their writing, their writing may be limited to the contents of model articles. Secondly, it takes time to process all of the pedagogical procedures. The researcher found time was pressing while attempting to carry out the instructional steps thoroughly because the teacher, the students and either the model articles or the students' writing samples form an interactive relationship in which all the three elements need to be involved 
in every single stage. Thirdly, the students might be reticent and even silent in EFL writing classrooms, which applies to Asian students in particular because they usually lack of learning motivation and class engagement (Szanajda \& Chang, 2015). It could take time and be difficult for instructors to implement inclass activities.

\section{Research Question 3: In terms of the students' perceptions toward the blog writing, are there any statistically significant differences after the treatments?}

As can been seen in Table 6, there were significant differences in terms of the students attitudes toward blog writing and affections toward blog writing. Accordingly, it was assumed that the affordance of blogs in the EFL university students' writing classrooms improved the students' mental status toward English writing. English writing is not merely related to one's English language ability, but also one's mental status that is also involved in the writing process. For example, the greater one's confidence, the better one's writing might be. Based on the results in the current study, one's attitudes and affections toward English writing might be enhanced through blogging because the students experienced different kinds of writing instruction in which they had more opportunities to interact with others, be exposed to language inputs, and be able to retrieve online resources.

Consequently, the researcher claims that blogs had greatly improved the students' writing competence both directly and indirectly. In terms of the direct dimension, the students were allowed reading others' work, sharing personal writings, retrieving information, giving comments and offering feedback. As for the indirect dimension, both the students' attitudes and affections might be improved through blogging because they had more interactive and communicative opportunities with others, which helped them understand collaborative writing. Therefore, the students had higher levels of satisfaction and lower levels of apprehension when blogging.

\section{Conclusions}

The researcher asserted that the students could benefit more from both the PGA and blogs for their English writing development. Golonka et al. (2014) mentioned that language learners are fond of using computer technology in their language learning, and they prefer using it to the traditional ones, so language learners might engage more in their language learning process, and they are likely to present more positive attitudes toward language learning. Finally, it is concluded that the integration of the blog and PGA developed the students' writing performance through the reading, sharing, giving, and receiving process in which they were writing collaboratively. As a result, the students' writing attitudes and affections toward writing were improved in this collaborative writing process, which strengthened the students' writing competence by increasing their writing interests and motivations. The research consequences demonstrated that the integration of the blog and PGA resulted in an intricate relationship in which each dimension intertwined with one another to enrich the students' writing performance directly and indirectly. A circulated cycle (Figure 1) was consequently formed to explain how the amalgamation of the blog and PGA facilitated the EFL university students' writing performance. 


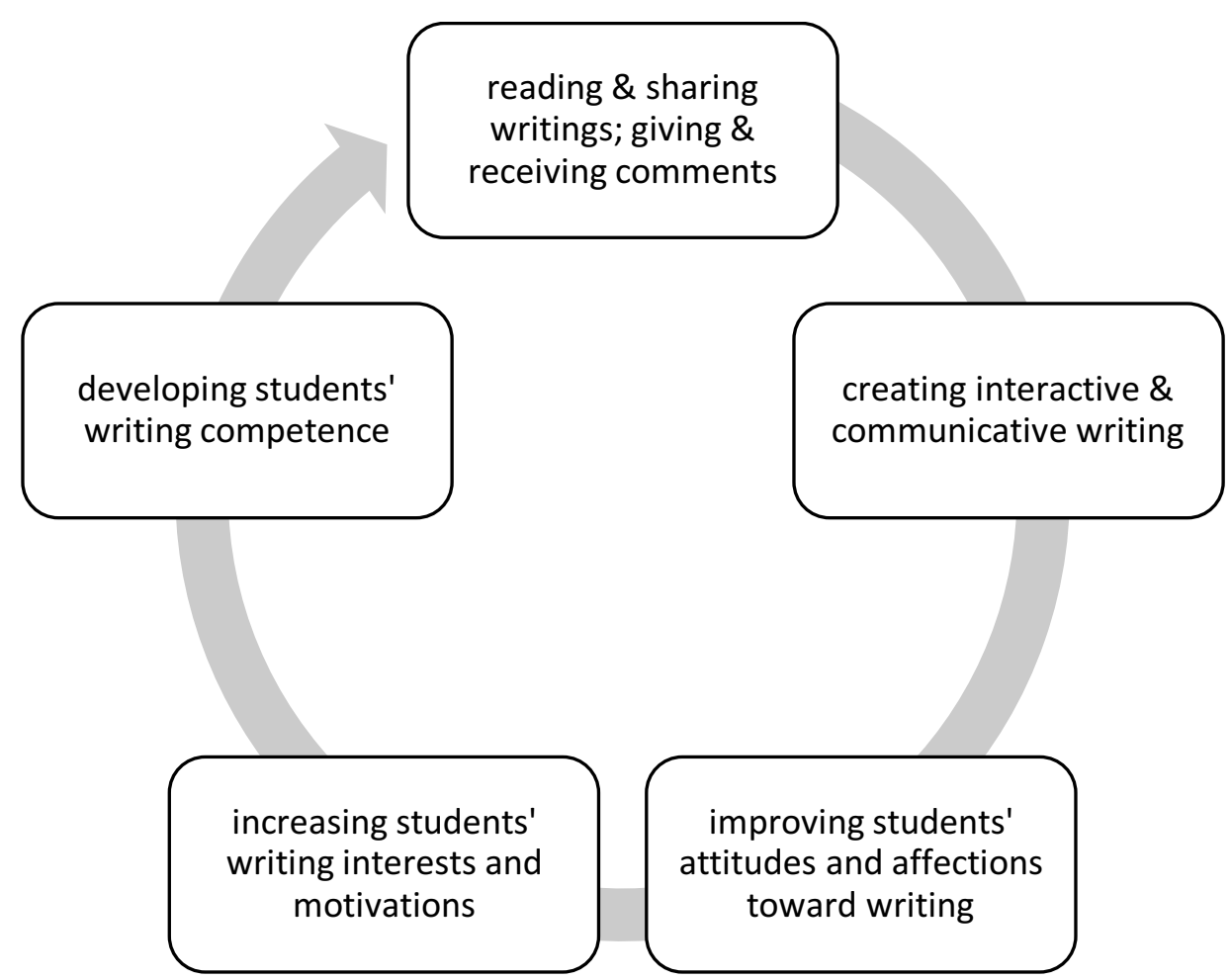

Figure 1. A Circulated Cycle for the Integration of Blog Writing and the PGA

\section{References}

Aljumah, F.H. (2012). Saudi learner perceptions and attitudes towards the use of blogs in teaching English writing course for EFL majors at Qassim University. English Language Teaching, 5(1), 100-116.

Armstrong, K. \& Retterer, O. (2008). Blogging as L2 writing: A case study. AACE Journal, 16(3), 233-251.

Arslan, R.Ş. \& Şahin-Kızıl, A. (2010). How can the use of blog software facilitate the writing process of English language learners? Computer Assisted Language Learning, 23(3), 183-197.

Ary, D., Jacobs, L.C., Sorensen, C. \& Walker, D.A. (2014). Introduction to research in education (9th ed.). Belmont, CA: Wadsworth, Cengage Learning.

Badger, R. \& White, G. (2000). A process genre approach to teaching writing. ELT Journal, 54(2), 153-160. Retrieved March 5, 2012 from http://eltj.oxfordjournals.org/content/54/2/153.abstract

Bijami, M. \& Raftari, S. (2013). Product, process, and genre approaches to writing: A comparison. The Iranian EFL Journal, 9(15), 9-18.

Boulos, M.N.K., Maramba, I. \& Wheeler, S. (2006). Wikis, bogs and broadcasts: A new generation of web-based tools for virtual collaborative clinical practice and education. BMC Medical Education, 6(41), 61-68.

Brace, N., Kemp, R. \& Snelgar, R. (2012). SPSS for psychologists (5th ed.). Basingstoke: Palgrave Macmillan.

Chapelle, C.A. (2010). Computer assisted language learning. In B. Spolsky \& F. M. Hult (Eds.), The handbook of educational linguistics (pp. 585-595). Oxford: Wiley-Blackwell.

Chen, C.H. (2013). 全民英檢一路通: 中級寫作能力測驗 [A pathway to the General English Proficiency Test: Writing proficiency test for the intermediate level]. Taipei: Crane Publishing.

Chen, S.J. (2014). 全球化下的臺灣英文教育: 政策、教學及成果 [The English education in Taiwan under the globalisation: Policy, teaching and performance]. 教育人力與專業發展 [Educator and Professional Development, 31(2), 7-20. 
Chen, Z.H. (August 11, 2015). 台灣雅思成績世界第18 [Taiwanese IELTS scores ranked 18th in the world]. 聯合報 [United Daily News]. Retrieved November 27, 2015 from http://udn.com/news/story/9/1114134-

\%E5\%8F\%B0\%E7\%81\%A3\%E9\%9B\%85\%E6\%80\%9D\%E6\%88\%90\%E7\%B8\%BE\%E4\%B8\%96 \%E7\%95\%8C $\%$ E7\%AC $\%$ AC18

Creswell, J. W. (2012). Educational research: Planning, conducting, and evaluating quantitative and qualitative research (4th ed.). Boston: Pearson.

Curtis, W., Murphy, M. \& Shields, S. (2014). Research and education Abingdon, Oxon: Routledge.

Dörnyei, Z. (2007). Research methods in applied linguistics: Quantitative, qualitative, and mixed methodologies. Oxford: Oxford University Press.

Fageeh, A.I. (2011). EFL learners' use of blogging for developing writing skills and enhancing attitudes towards English learning: An exploratory study. Journal of Language and Literature, 2(1), 31-48.

Fang, Y.C. (2010). Perceptions of the computer-assisted writing program among EFL college learners. Educational Technology \& Society, 13(3), 246-256.

Field, A. (2013). Discovering statistics using IBM SPSS statistics: And sex and drugs and rock ' $n$ ' roll (4th ed.). London: Sage.

Gall, M.D., Gall, J.P. \& Borg, W.R. (2010). Applying educational research: How to read, do, and use research to solve problems of practice (6th ed.). Boston: Pearson.

Gao, F. (2012). Probing into problems of writing approach of argumentations for in-service Masters of Education: From the angle of process genre pedagogy. Higher Education of Social Science, 2(3), 15-21.

Golonka, E.M., Bowles, A.R., Frank, V.M., Richardson, D.L. \& Freynik, S. (2014). Technologies for foreign language learning: A review of technology types and their effectiveness. Computer Assisted Language Learning, 27(1), 70-105.

Habul-Šabanović, I. (2015). Using blogs to promote student interaction and learning in EFL classes. Journal of Transdisciplinary Studies, 8(2), 9-22.

Hammersley, M. (2010). Reproducing or constructing? Some questions about transcription in social research. Qualitative Research, 10(5), 553-569.

Huang, H.C. (2015). From web-based readers to voice bloggers: EFL learners' perspectives. Computer Assisted Language Learning, 28(2), 145-170.

Hughey, J.B., Wormuth, D.R., Hartfiel, V.F. \& Jacobs, H.L. (1983). Teaching ESL composition: Principles and techniques. Rowley, Massachusetts: Newbury House Publishers, Inc.

Hyland, K. (2007). Genre pedagogy: Language, literacy and L2 writing instruction. Journal of Second Language Writing, 16(3), 148-164. Retrieved March 6, 2012 from http://www.sciencedirect.com/science/article/pii/S1060374307000495

Johnson, A. (2004). Creating a writing course utilizing class and student blogs. The Internet TESL Journal, 10(8). Retrieved May 15, 2012 from http://iteslj.org/Techniques/Johnson-Blogs/

Kervin, L. \& Derewianka, B. (2011). New technologies to support language learning. In B. Tomlinson (Ed.), Materials development in language teaching (2 ${ }^{\text {nd }}$ ed., pp. 328-351). Cambridge: Cambridge University Press.

Kitchakarn, O. (2012). Using blogs to improve students' summary writing abilities. Turkish Online Journal of Distance Education, 13(4), 209-219.

Li, Z.Q. (June 29, 2010). 英語充電站: 大學英文寫作歷練的核心策略 [English charging station: The core strategies for university English writing practice] 台灣立報 [Taiwan Lih Pao]. Retrieved November 27, 2015 from http://www.lihpao.com/?action-viewnews-itemid-29370 
Li, Z.Q. (2012). 台灣英語教育的演進與前瞻思維 [The evolution and vision of Taiwan's English education]. 台灣教育 [Taiwan Education Review], 674, 31-40. Retrieved November 27, 2015 from http://www.taodocs.com/p-10420568.html

Lin, C.F.C., Yu, W.C.W., Wang, J. \& Ho, M.H. (2015). Learning English Writing via A Web Digital Platform: A case of Taiwanese aboriginal nursing students' participation and learning outcomes. The Online Journal of Distance Education and e-Learning, 3(1).

Lin, M.H. (2014). Effects of classroom blogging on ESL student writers: An empirical reassessment. The Asia-Pacific Education Researcher, 23(3), 577-590.

Lin, M.H. (2015). Learner-centered blogging: A preliminary investigation of EFL student writers' experience. Journal of Educational Technology \& Society, 18(4), 446-458.

Lin, M.H., Groom, N. \& Lin, C.Y. (2013). Blog-assisted learning in the ESL writing classroom: A phenomenological analysis. Educational Technology \& Society, 16(3), 130-139.

Lin, M.H., Li, J.J., Hung, P.Y. \& Huang, H.W. (2014). Blogging a journal: Changing students' writing skills and perceptions. ELT Journal, 68(4), 422-431.

Liu, E.Z.F. \& Chang, Y.F. (2010). Gender differences in usage, satisfaction, self-efficacy and performance of blogging. British Journal of Educational Technology, 41(3), E39-E43.

Matsuda, P.K. (2003). Process and post-process: A discursive history. Journal of Second Language Writing, 12(1), 65-83. $\quad$ Retrieved March 22, 2012 from http://www.sciencedirect.com/science/article/pii/S1060374302001273

Maybin, J. (1994). Teaching writing: Process or genre? In S. Brindley (Ed.), Teaching English (pp. 186-194). London: Routledge.

McMillan, J.H. \& Schumacher, S. (2006). Research in education: Evidence-based Inquiry (6th ed.). Boston, MA: Pearson.

McMillan, J.H. \& Schumacher, S. (2010). Research in education: Evidence-based inquiry (7th ed.). Boston, MA: Pearson.

Miyazoe, T. \& Anderson, T. (2010). Learning outcomes and students' perceptions of online writing: Simultaneous implementation of a forum, blog, and wiki in an EFL blended learning setting. System, 38, 185-199.

Nardi, B.A., Schiano, D.J., Gumbrecht, M. \& Swartz, L. (2004). Why we blog. Communications of the ACM, 47(12), 41-46.

Nordin, S.M. \& Mohammad, N.B. (2006). The best of two approaches: Process/Genre-based approach to teaching writing. The English Teacher, 35, 75-85.

Normand-Marconnet, N. \& Cordella, M. (2012). Spanish and French foreign learners' blogging experience: Motivation and attitude. The JALT CALL Journal, 8(1), 3-16. Retrieved October 2, 2015 from http://journal.jaltcall.org/contents_8_1.html

Noytim, U. (2010). Weblogs enhancing EFL students' English language learning. Procedia Social and Behavioral Sciences, 2, 1127-1132.

Pawan, F., Paulus, T.M., Yalcin, S. \& Chang, C.F. (2003). Online learning: Patterns of engagement and interaction among in-service teachers. Language Learning \& Technology, 7(3), 119-140.

Selwyn, N. (2011). Education and technology: Key issues and debates. London: Continuum.

Silviyanti, T.M. \& Yusuf, Y Q. (2014). A one-stop class blog to promote collaborative writing activities. Malaysian Journal of ELT Research, 10(1), 31-45.

Sun, Y.C. (2010). Extensive writing in foreign-language classrooms: A blogging approach. Innovations in Education and Teaching International, 47(3), 327-339. 
Szanajda, A. \& Chang, W.Y. (2015). Encouraging student engagement in ESL writing classes in Asian classrooms: Recommendations for actions to be taken. Journal of Linguistics and Language Teaching, 6(2), 259-274.

Top, E. (2012). Blogging as a social medium in undergraduate courses: Sense of community best predictor of perceived learning. Social Media in Higher Education, 15(1), 24-28.

Torut, B. (2000). Computer-assisted language learning: An overview. Silpakorn University International Journal, 1(1), 130-153. Retrieved November 30, 2011 from http://www.journal.su.ac.th/index.php/suij/issue/view/11

Tuffs, R. (1993). A genre approach to writing in the second language classroom: The use of direct mail letters. Revue belge de philologie et d'histoire, 699-718. Retrieved May 31, 2012 from http://www.persee.fr/web/revues/home/prescript/article/rbph_0035-0818_1993_num_71_3_3899

Urbaniak, G. C. \& Scott, P. (1997). Research Randomizer. Retrieved November 10, 2013 from http://www.randomizer.org/

Warschauer, M. \& Liaw, M. L. (2011). Emerging technologies for autonomous language learning. Studies in Self-Access Learning Journal, 2(3), 107-118. Retrieved Novemer 29, 2015 from http://sisaljournal.org/archives/sep11/warschauer_liaw

Wu, W.C.V., Yen, L.L. \& Marek, M. (2011). Using online EFL interaction to increase confidence, motivation, and ability. Educational Technology \& Society, 14(3), 118-129. Retrieved November 28, 2015 from http://www.jstor.org/stable/jeductechsoci.14.3.118\#pdf_only_tab_contents

Wu, W.S. (2006). The effect of blog peer review and teacher feedback on the revisions of EFL writers. Journal of Education and Foreign Languages and Literature, 3, 125-139.

Yan, G. (2005). A process genre model for teaching writing. English Teaching Forum, 43(3). Retrieved March 19, 2012 from http://eca.state.gov/forum/vols/vol43/no3/p18.htm

Yang, S C. \& Chen, Y. J. (2007). Technology-enhanced language learning: A case study. Computers in Human Behavior, 23(1), 860-879. Retrieved February 20, 2012 from http://www.sciencedirect.com/science/article/pii/S0747563206000288

Zhytska, S.A. (2012). Computer assisted language learning. Information Technology and Security, 2(2), 2533.

Received: 05/03/2016

Accepted: 20/05/2016 